\title{
Speech Acts in ILC (Indonesia Lawyers Club) Talk Show Program
}

\author{
Lisna Rifkadiana. S \\ English Applied Linguistics \\ Postgraduate School \\ State University of Medan, \\ Medan, Indonesia \\ email: lisna_rifkadiana@yahoo.com
}

\author{
Busmin Gurning \\ English Applied Linguistics \\ Postgraduate School \\ State University of Medan \\ Medan, Indonesia
}

\author{
T.Thyrhaya Zein \\ English Applied Linguistics \\ Postgraduate School \\ State University of Medan \\ Medan, Indonesia
}

\begin{abstract}
This study was concerned with the use of speech acts in ILC (Indonesia Lawyers Club) Talk show program. The objective of this study was to describe the types of speech acts used by the host and the guests of ILC. Qualitative content analysis method was applied in this study. The sources of data were the host and the guests in ILC. The data of the study were the sentences and the phrases gathered from the conversation in the episodes of ILC. The finding of this study showed that four types of speech acts, namely rex'x presentative, directive, commissive, and expressive were used by the host and the guests of ILC, while declarative speech act was not found at all in the episodes of that talk show program. The dominant type of speech act used by the host was directive, while the guests dominantly used representative speech act.
\end{abstract}

Keywords: Speech Acts; Indonesia Lawyers Club;and Talk show program

\section{INTRODUCTION}

As a communication media giving people a lot of important information, television has been providing some models to enjoy it's informational purposes. One of them is talk show program. Talk show is one of the situations where conversation or dialog takes place. According to Timberg, 2002:5, atalk show or known also as chat showis a program where one person (or group of people) will discuss various topics which are leaded by a talk show host. Talk show is a televisison program in which people talk to exchange information one another. In other words, talking is the main tool of this TV program. Talking itself is done by speaking a language. When speaking a language, somebody is actually performing speech acts. It is based on the Searle theory (2000) stating that speaking a language is performing speech acts, such as making statements, giving commands, asking questions or making promises. Searle also states that all linguistic communication involves linguistics (speech) acts.

Nowadays, there are a lot of talk show programs we can watch on TV channels. One of them is ILC (Indonesia Lawyers Club). ILCis a talk show program on TV One discussing various hottest issues happen in Indonesia. This program is hosted by a senior journalist, Karni Ilyas. ILC presents a discussion and a debate about issues from various fields such as economics, politics, laws, socials, and so on. Generally, the guests invited in this program are important persons. They are ones who have great name in the world of politics, law, or art and culture in Indonesia, such as lawyers, parliamentarian, and even a minister. They will be giving their feed backs and analyses about the issue being discussed. Indonesia Lawyers Club is a program that will give the viewers insight and knowledge of the various problems being faced by this nation from a wider standpoint because in Indonesia Lawyers Club all the topics will always be thoroughly and clearly discussed from all sides. On the other hand, debates often happen in this program. The participants, include the guests, are even sometimes angry with one another when they are debating. This is what makes ILC different from other TV talk show programs. Based on this phenomenon, the researcher is interested to investigate the use of speech acts in Indonesia Lawyers Club TV program. This study is focused on the host's and the guests' utterances in order to know what types of speech acts performed during discussing the issue.

\section{REVIEW OF RELATED LITERATURE}

\section{Speech Acts}

Speech acts are actions performed through words. Austin (2009) explains that while using the language, people do not only produces an isolated series of sentences, but also perform an action. In other words, by using the language they either do something or make others do something. Thanking, requesting, and promising are some of them (Marquez, 2000).

Searle (2000) developed five basic types of illocutionary acts used to express someone's communicative intent purpose in speaking, namely; representatives, directives, commissives, expsressive and declaratives.

\section{a) Representatives}

Representatives are basic assertions made by the speaker, which contain a truth-value on the proposition. If someone says, "I state that the earth is flat", an assertion has been made, although the statement is false. Statement of fact, asserting, claiming, stating, informing, conveying, concluding, affirming, reporting, believing, denying, describing and predictingare some forms of representatives. The utterance below is the example: 
"Mr.Karni, what we also want to convey is that the policy package of law reform, the target is illegal levies, manifested in the ministry of transportation, is just one of the duties given by the officer, but there are also internal duties to Polri"

("Pak Karni, yang ingin juga kami sampaikan, bahwa paket kebijakan reformasi hukum yang ditargetkan pungli itu yang diwujudkan di kementrian perhubungan adalah merupakan salah satu tugas saja yang diberikan oleh petugas tetapi ada tugas tugas yang internal juga kepada polri”)

\section{b) Directives}

Directive is an attempt of the speaker to get hearer to do something for him. This act may be expressed in different forms, such as in question form or in command form, like "would you mind passing me the salt?"or "pass the salt". In either case, the speaker wants the hearer to pass the salt. Other forms of directive are, warning, commanding, admonishing, ordering, dismissing, excusing, forbidding, instructing, advising, begging, challenging, insisting,urging, requesting, questioning, pleading, entreating, daring, inviting, suggesting, and permitting. For example:

"Why didn't 'Polri' go inside first before doing the operation at Department of Transportation? Anyway, there are also a lot of posts of services in 'Polri' which many people complain about all this time?"

("Kenapa Polri tidak ke dalam dulu operasinya baru ke Perhubungan? Toh, di Polri juga banyak sekali pos - pos pelayanan yang selama ini rakyat banyak mengeluh")

\section{c) Commissives}

Searle (1979) defines commissives express the speaker's intention and believe that his utterance obligates him to do something (perhaps under certain conditions). Commissives then are those illocutionary acts whose point is to commit the speaker (again in varying degrees) to some future course of action.

Commissives speech act binds the speakers to carry all the things mentioned in the utterance, for example, promising, threatening, expressing readiness, offering, refusing, vowing, pledging, guaranteeing, agreeing, consenting, volunteering and swearing, i.e. "I promise to be there in the morning". The utterance binds the speaker to be there in the following morning. This brings consequences for him to fulfill what had been spoken. In using the commissives, the speaker is making an understood contract with the hearer that will be carried out. For example:

1) "Uber mau kerja sama dengan dia, boleh" ("Uber wants to cooperate with it, why not")

2) "AY : Percaya deh, gak miskin dan gak sengsara." ("Trustme, you won't be poor nor miserable")

\section{d) Expressive}

When the speaker expresses a psychological statement about the situation or statement of affairs denoted by proposition such as thanking, apologizing, consoling, congratulating, greeting, welcoming and deploring, is called expressive.
Searle (1979) states expressives are acts to express the psychological state specified in the sincerity condition about a state of affairs specified in the propositional content. The paradigms of expressive verbs are "thanks", "congratulate", "apologize", "condole", "deplore", and "welcome". Expressive speech acts express psychological states within the speaker and tell how the speaker feels. The utterance below is the example of expressive speech act:

"That's why we apologize, if at the next time, the issues of illegal levies will increasingly scrolling."

(Makanya kami ini minta maaf kalau ada berita -berita tentang pungli ini kedepannya semakin menggulir)

\section{e) Declaratives}

Declaratives are very special category of speech acts.Theseare statements made by authority, which cause immediate action from the utterance. These, sometimes are only effective when stated by the appropriate authority. For example, "I hereby pronounce you man and wife" in turn officially causes the couple to be wed, and can take effect only if said by a priest or someone who carries authority to wed individuals. The examples of declaratives are declaring war, seconding a motion, adjuring a meeting, firing, nominating, christening, finding guilty/innocent, betting, passing (in a game), divorcing, baptizing, arresting and resigning.

\section{Talk Show Program}

Timberg (2005:5) defines talk show as a program where one person (or group of people) will discuss various topics which are leaded by a talk show host. In talk show, the participants are usually stimulated, guided and facilitated by the host to present particular information exchange, related to personal experience, judgment or common sense.

The aim of talk shows is to deliver useful information to the viewers and entertain them at the same time (Munson, 1993). He also added that questions are central to the structure of talk shows and are quite effective in exploring guest' professional and personal lives. A talk show can consist of invited guests insisting on their facts and their positions, and arguing about the truth, or it can consist of the presenter encouraging random callers to express themselves on what they have heard on the program, or on a particular issue. Often talk shows are a mixture of both formats. On talk shows, people talk, they express their opinions; they are in conflict with each other. But it is the impact of the program on the listeners which matters most, not the status of the guests or the personality of the presenter. What is important is how the listeners are affected by what they hear.

\section{ILC (Indonesia Lawyers Club)}

Indonesian Lawyers Club is one of the popular news talk show program on private television station, $T V$ one. Facts show that Indonesian Lawyers Club is a favorite television program that awarded Panasonic Award in 2013 in the category of talk show and News and Information Program(http://life.viva.co.id/news/read/401390-indonesialawyersclubsabetpenghargaan-bergengsi-panasonic).Indonesia 
Lawyers Club also has fans in face book social network about sixty nine thousand and four hundred people (https://idid.facebook.com/IndonesiaLawyersClubTVOne).

Indonesia Lawyers Club (abbreviated ILC; formerly known as Jakarta Lawyers Club) is a talk show that aired on TV One. This talk show is guided by a senior journalist who has a background as a scholar of law and journalistic, Karni Ilyas and is supported by the experts in their field. The show is broadcasted on Tuesday at $19.30 \mathrm{pm}$ and Sunday $22.30 \mathrm{pm}$. The characteristic of the program is taking about the foremost law. This program discusses issues of law violations that occur in Indonesia. The host presents and develops the issues of the program by having map concept. The topic is developed into several themes which refer to the topic.

\section{RESEARCH DESIGN}

This study applied qualitative research design. According to Patton (1990:36), in qualitative method, data are collected in the forms of words, sentences or pictures in which the meaning is more significant than numbers. Meanwhile, Arikunto (2009:195) states that qualitative research is a descriptive research because this research tries to describe data with words or sentences which are separated by category to obtain conclusions. Further, this study employs content analysis to analyze the data. Fraenkel and Wallen (2007: 483) definescontent analysis as a technique that researchers can use to examine human behavior indirectly through analysis of their communications such as textbooks, essays, newspapers, novels, articles, magazines, songs, advertisement images and all types of communications that can be analyzed. According to Weber (1990:117), content analysis is a research method that uses a set of procedures to make valid inferences from text and document.

The source of data in this study were the host and the guests of Indonesia Lawyers Club talk show program. The data of the study were the sentences and phrases gathered from the conversation between the host and the guests in the episodes of ILC talk show program.

The technique used to collect the data in this study is a document analysis. According to Bowen (2009) Document analysis is a systematic procedure for reviewing or evaluating documents - both printed and electronic (computer-based and Internet-transmitted) material.

In qualitative research, the instrument or the research tool is the researcher itself (Sugiono, 2009: 305).In this study, therefore, the researcher is the key of instruments collecting the available data of the ILC episodes in Youtube website. In analyzing the data of the study, Miles, Huberman and Saldana techniques (2014) were used. Miles, Huberman and Saldana elaborated some steps of analyzing data, they are: (1) datacondensation (2) data display (the step to show/make the visual of the data in the form of chart, diagram, matrix, or graphic) and (3) data verification/conclusion (the last step to draw conclusion from the data shown in the data display).

\section{DATA ANALYSIS, RESEARCH FINDINGS AND DISCUSSION}

Having been analyzed, the data showed that there were four types of speech acts occured in the utterances of ILC's participants. The more detail information about the using of speech acts by each of participants were explained below.

\section{Data analysis}

Types of Speech Acts Used by the Host and the Guests

During the process of discussion, there were so many utterances among the hosts and the guests. The text of the conversation were transcribed through observation of video recording and were analyzed by using the theory of speech acts. The utterances (phrases, clauses, and sentences) used by the host were grouped and classified into types of speech acts and their forms.

TABLE 1. THE PERCENTAGE OF SPEECH ACTS USED BY THE HOST AND THE GUESTS

\begin{tabular}{|c|c|c|c|c|}
\hline No & $\begin{array}{c}\text { Types of } \\
\text { speech acts }\end{array}$ & Form & $\begin{array}{c}\text { Tota } \\
1 \\
\end{array}$ & $\begin{array}{c}\text { Percentag } \\
\text { e }(\%) \\
\end{array}$ \\
\hline \multirow[t]{12}{*}{1} & Representati & Informing & 387 & 47.77 \\
\hline & ve & Believing & 4 & 0.50 \\
\hline & & Concluding & 4 & 0.50 \\
\hline & & Reporting & 4 & 0.50 \\
\hline & & Claiming & 7 & 0.86 \\
\hline & & Stating & 167 & 20.61 \\
\hline & & Emphasizing & 10 & 1.23 \\
\hline & & Asserting & 20 & 2.46 \\
\hline & & Affirming & 3 & 0.38 \\
\hline & & Conveying & 6 & 0.75 \\
\hline & & Predicting & 3 & 0.38 \\
\hline & & Denying & 3 & 0.38 \\
\hline \multirow[t]{7}{*}{2} & Directive & Questioning & 143 & 17.65 \\
\hline & & Advising & 2 & 0.24 \\
\hline & & Requesting & 2 & 0.24 \\
\hline & & Ordering & 1 & 0.12 \\
\hline & & Excusing & 1 & 0.12 \\
\hline & & Instructing & 13 & 1.60 \\
\hline & & Commanding & 6 & 0.75 \\
\hline \multirow[t]{4}{*}{3} & Expressive & Greeting & 5 & 0.61 \\
\hline & & Apologizing & 3 & 0.38 \\
\hline & & Welcoming & 1 & 0.12 \\
\hline & & Thanking & 5 & 0.61 \\
\hline \multirow[t]{3}{*}{4} & Commissive & Agreeing & 8 & 1.00 \\
\hline & & Guaranteeing & 1 & 0.12 \\
\hline & & Offering & 1 & 0.12 \\
\hline 5 & Declarative & - & - & - \\
\hline \multicolumn{3}{|c|}{ Total } & 810 & 100 \\
\hline
\end{tabular}

Table 1 presented that four types of speech acts were used by the host and the guests, namely representatives, directives, expressives and commissives. From those four types of speech acts, representatives in questioning form was the dominant one, namely 387 out of 810 utterances or $47.77 \%$. As the host, Karni Ilyas asked so many questions to get a lot of 
informations from the guests about the problem being discussed. He also asked the point of view of some guests related to the topic. The guests, as the result, had to reply the questions and give the informations needed by the host. Meanwhile, the commissive was the type of speech act that least used by the host and the guests. This type of speech acts was used in the form of agreeing, offering and guaranteeing. From the three forms, offering and guaranteeing were the least ones. Each of them consisted only one utteraance from the whole conversations.

In their conversations, both the host and the guests performed their speech acts through four ways, namely direct, indirect, literal and non literal which were well understood by all the guests of the talk show program.

\section{The Use of Representative Speech Acts by the Host and the Guests}

There were some forms of representative speech acts used by the host and the guests during discussing the topic such as informing, asserting, denying, stating, affirming, conveying, predicting, and emphasizing. Eventhough the host behalf was to get information from the guests, but in this case, informing was also dominantly used in order to deliver important informations that needs to be known by either the guests talking to him, other guests, or the viewers of the talk show program. Meanwhile, the guests, as they should do, gave informations to the host by answering no matter what the host asked them. As the result, representative, in the form of informing was the dominant form of speech acts used by either the guests or by the host of ILC talk show program.

The following utterance was the example of informing representative speech act occured in the conversation between the host and the guest of ILC talk show program.

KI : Itu kalau pelaut itu Pak, yang sering saya dengar, dia udah di darat, mau naik lagi nunggu izinnya itu berbulanbulan sampai hasil dia bertahun - tahun di laut tadi habis lagi Pak karena nganggur.

(I heard that if a sailor is already on land, and then he wants to sail again, he will be so tired to look forward to getting the permission letter that the salary he got from sailing for years is gone because of unemployment).

Stating was the second dominant form of representative speech acts used by the host and the guests of ILC talk show program. It was performed 135 times by the guests. It means that this form took 23.57 percent of the whole representative forms occured in the guests' utterances. Meanwhile, the guests uttered statements to say his belief or his point of view on something as responses to what the guests uttered. The following were the examples of representative speech acts in the form of stating:

KI : Ya Masyarakat tentu aja berharap itu benar - benar terjadi karena itu yang akan untung masyarakat dan perekonomian kita juga.

(Yeah, the people certainly hope that it will really happen because it will benefit our society and economy too)

\section{The Use of Directive Speech Acts by the Host and the Guests}

The most dominant form of directive speech acts used by the host was questioning. The host performed this form of directive speech acts because his main role in this program was to get the accurate information related to the topic from the authentic interviewees. The host questioned the guests in some ways. He sometimes asked the guests directly (in question form) and sometimes indirectly (in declarative form). For instance, in example (a), the host uttered a sentences in declarative form but it functioned as question. In other words, the host performed it indirectly. In the example (b) the host asked the guest in interrogative form which means that he uttered the question in direct form. From 131 questions uttered by the host, all of them were in the literal form. It was to prevent the guests from being misunderstanding in getting the host's intent.

a) KI: Saya sebenarnya mau tahu detilnya ketika POLRI mendadak ke departemen perhubungan dan koordinasinya sejauh mana dan infonya dari mana dan kenapa perhubungan yang dijadikan contoh soal pertamanya.

(I actually wanted to know the details when the National Police arrived suddenly at the transportation department and how far the coordination was and where the information was from and why the transportation department was the first example of the problem)

b) KI : Yang hubungannya dengan perintah presiden itu di Perhubungan dulu atau di Polri dulu?

(Which one did relate to the president's order, in Transportation Department first or at the National Police first?)

The second form of directive speech acts used by the host was instructing. Before giving quetions to each guest, the host gave instruction about who will get the next chance to speak. The guest asked to speak by the host could start speaking only after the host had instructed him to do it. The same way was applied when the guest's speaking stopped. All the instructions given by the host were in direct and literal form. It was done to make the instruction clear for all the guests.

a) KI : Silahkan Pak Daelani. (Please Sir Daelani)

b) KI : Sekarang Pak Pieter. (Now Mr. Pieter)

Another form of directive speech acts perfomed by the guests was advising. In telling their information, some guests also gave some advices for other guests or for the viewer of the talk show program (ILC). The following utterances were the example of the advices:

a) EA : Dan saran saya sebagai wakil rakyat kepada Uber, ataupun Gojek dan lain lainnya tolong ikutin aturan 
(And my advice as a people's representative to Uber, or Gojek and others please follow the rules)

b) IPB : Jadi kita harus sama - sama mengatakan selamat tinggal pungli dan kita harus mau masuk kepada suatu tahap perubahan kehidupan yang lebih baik lagi terutama dalam melakukan pelayanan kepada publik.

(So we have to say - congratulations on staying illegal and we have to be willing to enter a better stage of life change especially in doing services to the public)

\section{The Use of Expressive Speech Acts by the Host and the Guests}

Expressive speech act was one of the speech act type which was rarely performed by the host. This type of speech act was used by the host in three forms namely greeting, welcoming, and thanking. It was just used by the host in certain circumtances. For instance, when he welcomed and greeted an important interviewee who had just arrived at the talk show room (a). The host also performed the expressive speech act when he replied the greeting of a guest having a speaking chance (b). Another circumtance in which the host performed the expressive speech act was when he thanked the guest for giving a satisfying explanation for him (c)

a) KI: Selamat datang, Pak Menteri PAN, Pak Asman Abnur.

(Welcome the Minister of Utilization of State Apparatus, Mr Asman Abnur)

b) KI : Waalaikum Salam Warohmatullah (Peace and mercy of God upon you too)

c) KI : BaikPak Menteri, terima kasih atas tambahannya.

(Well Mr Minister, thank you for the addition)

The host performed all the form of expressive speech acts in direct and literal way as the host uttered them to thank and to greet the guest, while the both expressions could only be uttered direcly and literally.

Expressive speech act was also used by the guests during the discussion. One of them was thanking. The following utterances were the example of thanking performed by the guests.

a) RA:Terima Kasih banyak Bang Karni. (Thank you so much Mr. Karni)

a) EA : Baik. Terima Kasih Bang Karni (well, thank you Mr. Karni)

The second form that was also performed by the guests was greeting. This form of expressive speech acts was performed in beginning of conversation between the host and a guest getting a chance of speaking. The utterances below were some of the examples:

a) AY : Assalamualaikum Warahmatullahi wabarakatuh.
(May the peace, mercy, and blessings of Allah be upon you.)

b) SH : Yaa.. Selamat malam Bang Karni, Bapak Bapak narasumber dan Ibu Bapak yang hadir dalam forum ini, serta pemirsa semuanya.

(Well, Good evening Mr. Karni, Ladies and Gentlemen who were present at this forum, as well as all viewers)

The last form of expressive speech acts used by the guests was apologizing. There were only three utterances showing the apologizing of the guest. The following utterances were some of the examples:

a) PY : Saya mohon maaf pada teman - teman semua (I apologize to all my friends here)

b) PY: Maaf ya buk ya I'm sorry, Maam)

\section{The Use of Commissive Speech Acts by the Host and the Guests}

Agreeing and offering were two forms of commissive speech acts used by the host during discussing the topic. In the example (a) the host agreed to the guest's statement by confessing that both Grab car and Gojek (taxibike) were transportations with online aplication. This agreeing utterance made an understood contract between the host and the guest about the concept of online transportation and then committed the speaker to some event or action related to the concept of the online trasportation. Meanwhile, in the example (b) the host offered the guests to get the same question like he was asking at that time. This second utterance committed the speaker to do the same thing to another guest, namely asking the questions. Both of those utterances were uttered in direct and in literal way.

a) KI : Ya, dua-duanya memang aplikasi online. (Yes, both of them are online taxies)

b) KI: Atau nanti untuk perusahaan taksi yang umum saya juga akan nanya itu.

(Or later I will ask about it to common taxi companies too)

Commissive was the type of speech acts that is least perfomed by the guests. Agreeing was one of the form of commissive used in this talk show program. The utterances below were the examples of the agreeing :

c) SH : Iya. Itu benar sekali Pak Karni (Yes, that is totally right, Mr. Karni)

d) EA : Iya normal saja Pak (Yes, it's just normal, Sir)

The second form of commissive was guaranteeing. It was used by a guest to persuade other guests or viewers to do his suggestions. For example: 
e) EA : Gak susah kok bikin ijinnya

(It's not hard how to make a permit)

\section{FINDINGS}

Based on the data analysis, it was found that during the process of discussion, four types of speech acts were used, namely representatives, directives, commissive, and expressive. Yet, not all the participants used them. The most dominant type of speech acts was representative. This type of speech acts was used dominantly by the guest. The guests used the representative acts in form of conveying, reporting, asserting, confirming, and etc. Directive speech acts was frequently used by the host. This kind of speech act was used by the host in form of questioning, commanding. Both commissive and expressive are the types of speech acts that least used by either the host or the guest of Indonesia Lawyers Club talk show program. Expressive speech act was used by both the host and the guests in form of thanking and greeting. This type of speech act was used by the host and the guest when the chance of talking was given to the new speaker. On the other hand, commissive was used by the guest and the host in form of guaranteeing and promising.

\section{DISCUSSION}

Searle (2000) developed five basic types of speech acts that used to express someone's communicative intent purpose in speaking namely; representatives, directives, commissive, expressives and declaratives. During discussing the topics, four out of five speech act types were used by both the host and the guests of ILC Talk show program. The four types were representatives, directives, commissives, and expressives speech acts. In Hashempour's study (2016) "A Study on Iranian Funeral Posters: Speech Acts Analysis", it was found that out of five types of speech acts, only four types of them were used in the texts. Therefore it is concluded that theory of speech acts proposed by Searle was applied both in this study and Hashempour's. On the other hand, Arief's (2012) in his study "Speech Acts Used in Courtroom Text in Langsa", found that all types of speech acts were applied in the courtroom. It is concluded that the performing of speech acts types may be different in different fields. In this study, besides directives speech act in the form of questioning was dominantly used by the host, it was found that representatives speech act in the form of informing was also frequently used by the host. Eventhough the behalf of the host was to get information from the guests, but he also delivered information when it was needed, for instance when he responded something that considered wrong or mistaken.

\section{CONCLUSION}

Four types of speech acts were used in ILC (Indonesia Lawyers Club) Talk Show program, namely representative, directive, commissive, and expressive. Those four types of speech acts were used by either the host or the guests of ILC.
On the other hand, declarative speech act was not performed at all in this talk show program. The most dominant type of speech acts used by the host was directive in the form of questioning. Meanwhile, representative in the form of informing is frequently used by the guests of ILC.

\section{REFERENCES}

[1] Asher, N. \& Lascarides, A.;1; (2006). Indirect speech acts. Synthese, $128 \quad(1 / 2), \quad 183-228 . \quad$ Retrieved from http://www.jstor.org/stable/20117151.

[2] Austin, J. L. 1962. How to do things with words. Cambridge: Harvard University Press.

[3] Bach, K. and Harnish, R. 1980. Linguistic Communication and Speech Acts. Massachusetts: the MIT Press.

[4] Bogdan, R. and Biklen, S.K. (1992).Qualitative Research for Education. Boston: Allyn and Bacon

[5] Bowen, Glenn A. 2009. Document Analysis as a Qualitative Research Method. Qualitative Research Journal, Vol.9, no.2, pp.27-40. Doi: 103316/QRJ0902027

[6] Illie, C. 2006. 'Talk Show'. Journal of Pragmatics, 489-493

[7] Miles, M.B., and Huberman, A.M. 1984. Qualitative data analysis. California: Sage Publication

[8] Munson, W. (1993).All Talk: The Talk Show In Media Culture. Philadelphia: Temple University Press.

[9] Searle, J. R. 1979. Expression and Meaning: Studies in the theory of speech acts. Cambridge: Cambridge University Press.

[10] Suprapto, H. 2013. Indonesia Lawyers Club Sabet Penghargaan Bergengsi Panasonic. TimViva, retrieved on August 2nd, 2017 on https://www.viva.co.id

[11] Timberg, B. M. 2002. Television talk: a history of the TV Talk show, Texas: University of Texas Press

[12] Weber, Rober Philip. 1990. Basic Content Analysis. California: Sage Publication 